\title{
PENINGKATAN SUBJECTIVE WELL-BEING IN SCHOOL PADA SISWA MELALUI "PEER SUPPORT AND TEACHING METHOD PROGRAM"
}

\author{
Puspita Adhi Kusuma W' ${ }^{1}$, Lucia Voni Pebriani ${ }^{2}$, Whisnu Yudiana ${ }^{3}$ \\ ${ }^{1,2,3}$ Fakultas Psikologi, Universitas Padjadjaran, Bandung, Indonesia \\ E-mail: puspita.adhi@unpad.ac.id
}

Diserahkan 25 November 2018; Diterima 01 Maret 2019; Dipublikasikan 01 April 2019

\begin{abstract}
ABSTRAK
Siswa yang merasa puas akan kehidupannya di sekolah merupakan indikator dari subjective well-being (SWB) in school yang tinggi. Penelitian-penelitian mengenai SWB siswa di sekolah menjadi penting untuk dilakukan karena hal ini berdampak pada prestasi akademik yang lebih baik, kreativitas yang lebih tinggi, dan penurunan angka membolos. Maka dari itu, penting untuk mengembangkan sebuah program dalam rangka meningkatkan subjectivewell-beingsiswa. Penelitian ini bertujuan untuk mengetahui apakah program intervensi kepada guru dan siswa berhasil meningkatkan subjective well-being siswa di sekolah. "Peer Support and Teaching Method Program" yaitu program peningkatan SWB siswa yang diberikan kepada guru dan siswa. Guru diberikan pelatihan mengenai metode mengajar konstruktivis, sedangkan siswa akan diberikan pelatihan sosial untuk meningkatkan kerjasama, empati dan dukungan antar teman sebaya. Partisipan dalam penelitian ini adalah 32 siswa kelas XI Akutansi, dimana 32 siswa tersebut diberikan pelatihan sosial, dan guru yang mengajar di kelas tersebut diberikan pelatihan metode mengajar dengan pendekatan konstruktivis. Analisis statistika menggunakan Wilcoxon Signed Rank Test untuk mengukur perbedaan data prestest dan posttes. Hasil menunjukkan bahwa pelatihan "Peer Support and Teaching Method Program" secara signifikan mampu meningkatkan subjective well-being siswa di sekolah. Pada penelitian ini membuktikan bahwa pengajaran berbasis konstruktivis dan para siswa yang menerapkan empati, kerjasama dan saling mendukung antarteman membuat siswa yang ada di kelas tersebut mempunyai perasaan yang lebih baik di sekolah dan merasa lebih puas dengan kehidupannya di sekolah. Para pemangku kebijakan di sekolah dapat menggunakan program ini sebagai salah satu cara untuk meningkatkan subjective well-being in school pada siswa.
\end{abstract}

Kata Kunci:Kesejahteraan Subjektif di sekolah, Pelatihan "Peer Support and Teaching Program"

\section{THE ENHANCEMENT OF SUBJECTIVE WELL-BEING OF STUDENTS IN SCHOOL THROUGH "PEER SUPPORT AND TEACHING METHOD PROGRAM”}

\begin{abstract}
Student that satisfied with their life at school indicate they have high subjective well-being in school. Researches about subjective wellbeing in school become important to do because it haveimpact on better academic performance, higher creativity, and a decrease in truant numbers. Therefore, it's important to develop a program to increase student's subjective well-being. The research aimed to find out the effectiveness of "Peer Support and Teaching Method Program" to increase student's subjective well-being. This program was delivered to students and teachers. Teachers was trained about teaching method which tailored to the student needs, while students was trained with social skills to improve cooperation, empathy and peer support. The participant is 32 students from Accounting Class grade 11. 32 students was trained with social skill training and teachers that teach in the Accounting class was trained with teaching method using constructivist approach. Statistical analysis used Wilcoxon Signed Rank Test to test the difference of pretest and posttest. Result showed that the training of "Peer Support and Teaching Method Program" was significantly could improve the student subjective well-being.The research proved that teaching with constructivist approach and student that have empathy, cooperation and support each other make students in the classroom have better feelings and more satisfied with their life at school. School administrators could running this program as one of intervention to improve student's subjective well-being in school.
\end{abstract}

Keywords :Subjective Well-Being in school, "Peer Support and Teaching Method Program.

\section{PENDAHULUAN}

"Well-being" didefinisikan sebagai kombinasi dari perasaan baik dan berfungsi dengan baik" (Huppert \& Johnson, 2010). Diener dkk (2009) menyebutkan sebagai konstruk psikologis, yang dioperasionalkan melalui hadiah dan hubungan yang positif dengan orang lain atau mempunyai perasaan kompeten atau percaya diri dan sebuah kepercayaan bahwa hidup itu bermakna dan bertujuan. Subjective Well-Being merujuk pada penilaian kognitif dan afektif seseorang akan hidupnya sebagai sesuatu yang memuaskan atau tidak (Diener, Lucas, dan Oishi, 2002). 
Pengaruh dari subjective well-being seseorang telah banyak diteliti pada beberapa domain kehidupan, misalnya di sekolah. Roeser at al (1999) meneliti bagaimana fungsi akademis dipengaruhi oleh kesehatan mental yang buruk yang berkaitan dengan emosi negatif dan motivasi akademis yang rendah pada anak kelas 8 dan 9. Data mereka menunjukkan bahwa siswa dengan kesehatan mental yang positif dan motivasi akademis yang tinggi adalah anak-anak dengan peringkat terbaik, sedangkan siswa dengan motivasi rendah dan emosi serta pikiran negatif yang sering adalah anak-anak dengan peringkat terbawah.

Beberapa penelitian juga mencatat akan pentingnya siswa memiliki subjective well-being yang baik di sekolah. Penelitian Abele (1995) menunjukkan bahwa subjective well-being yang tinggi mempunyai pengaruh yang menguntungkan pada perfomansi kognitif. Penelitian eksperimental Abele (1995) ini mengindikasikan bahwa mood yang positif menghasilkan perfomansi yang meningkat, sedangkan mood yang negatif menghasilkan perfomansi yang menurun pada subjek-subjek yang sedang mengerjakan puzzle-puzzle logis. Sama halnya dengan Abele (1995), Grren and Noice (1998) dan Isen (2008), mengungkapkan bahwa mood yang positif memicu kreatifitas dan imaginasi, hal ini ditemukan pada subjek-subjek dalam penelitian ini bahwa mereka yang mempunyai mood positif mempunyai gaya berpikir yang lebih fleksibel dan konteks kognitif yang lebih luas daripada subjek-subjek dengan mood yang negatif. Fungsi akademis yang terganggu dikarenakan menurunnya well-being adalah hasil yang tidak menguntungkan dan dapat berlangsung lama sampai usia dewasa. Academic Success, yang dimanifestasikan pada prestasi yang bagus di sekolah, adalah sebuah pusat sumber distribusi dari adanya kesempatan dalam kehidupan dan perspektif untuk masa depan. Academic success mempunyai pengaruh terhadap indikator kesuksesan secara materi, seperti penghasilan, dan status sosial (Johnson et al, 2010; Steinbach, 2006).

Besarnya dampak yang terjadi karena subjective well-being seseorang membuat para ahli mengembangkan program-program untuk meningkatkan subjective well-being (kesejahteraan psikologis) para siswa. Bernard \& Walton, 2011; Huppert \& Johnson, 2010; Peterson \& Seligman, 2004; Seligman et al, 2009; dan Waters, 2011 mengembangkan program-program pendidikan positif yang akan memberikan ketrampilan kepada siswa untuk memperkuat kekuatan dan resiliensi mereka, sehingga dapat menangkal pengaruh dari datangnya permasalahan-permasalahan psikologis. Waters (2011) melakukan review 12 sekolah yang mengembangkan sebuah program berbasis psikologi positif untuk meningkatkan kesejahteraan psikologi para siswa. Bukti-bukti menunjukkan bahwa programprogram tersebut signifikan berkorelasi dengan meningkatkan kesejahteraan subjketif para siswa. Beberapa program terbukti efektif dalam meningkatkan SWB siswa di sekolah. Shoshani dan Steinmetz (2014) melaporkan keberhasilan program Positive Psychology dalam menurunkan angka kecemasan dan simptom depresi diantara pada participan. Intervensi tersebut memperkuat harga diri, efikasi diri, optimisme dan mengurangi sensitivitas interpersonal. Penguatan akan well-being dan harga diri ini juga dilakukan oleh Wellington College dengan mengajarkan "Well-being Program”, dimana semua siswa pada 4 tahun pertama menerima 1 pelajaran mengenai well-being. Kursus tersebut meliputi kesehatan fisik, perspektif, keterlibatan, hubungan yang positif dan kata (sustainably living) dan pemaknaan dan tujuan (Morris, 2009).

Seligman (2011) berpendapat bahwa asal-usul kesejahteraan psikologis berasal dari lingkungan. Untuk siswa, sekolah merupakan setting yang ideal untuk mengajarkan "well-being" karena remaja menghabiskan banyak waktu mereka di sekolah. Para ahli menekankan tiga alasan mengapa mengajarkan "well-being" itu menjadi penting untuk dilakukan, pertama adalah peningkatan dari kekuatan akan emosi positif diantarra para remaja, keterlibatan dan pemaknaan kehidupan akan menjadi penangkal dari depresi, meningkatkan kepuasaan hidup, memfasiltasi pembelajaran dan berpikir positif (Seligman et al, 2009). Yates (2007) memberikan penekanan, bahwa pendidikan mempunyai tujuan yang signifikan untuk membantu para remaja dalam mengembangkan ketrampilan dan kemampuan untuk hidup dengan lebih baik dan menambah kohesi social. The National Scientific Council on Developing Child (2006) menyatakan bahwa fokus harus ditujukan pada emotional well-being (kesejahteraan emosional) para siswa dan kapabilitas sosial yang terkoneksi dengan kemampuan kognitif dan akademis. Penemuanpenemuan ini mengindikasikan bahwa well-being sebagai sebuah indikator untuk mempromosikan kesehatan mental dari para remaja sudah seharusnya diajarkan di sekolah.

Walaupun banyak para ahli yang memperdebatkan efektifitas dari program peningkatan well-being ini serta anggapan bahwa program-program ini hanya menghabiskan biaya dan waktu, namun beberapa bukti menunjukkan bahwa program peningkatan well-being ini mampu meningkatkan motivasi siswa, energi, dan sumber-sumber untuk mendukung mata pelajaran yang pada akhirnya membantu siswa dalam meningkatkan prestasi akademik mereka (Spence and Shortt, 2007).

Banyak faktor yang mempengaruhi kesejahteraan subjektif siswa, dan hal tersebut menjadi dasar sebuah program dilaksanakan. Sebagian besar program peningkatan kesejahteraan psikologis siswa berfokus pada penguatan karakter hubungan sosial di sekolah dan metode pengajaran yang mempu mendukung siswa untuk lebih terlibat dan mempunyai makna dalam pelajaran yang mereka dapatkan. Hal ini dikarenakan beberapa penelitian menemukan bahwa learning environment (lingkungan pembelajaran) berkorelasi terhadap subjective well-being in school dengan dimensi 
peer relation (hubungan dengan teman sebaya) dan academic teaching (pembelajaran akademis) sebagai prediktor tertinggi pada subjective well-being in school (Wijayanti \& Suliostibudhi, 2018; Capella et al, 2014; Tharani, Husan dan Warwick 2017; Chen chen and Fury, 2017 ; Tennant, et.al, 2014). Semakin positif siswa mempersepsi lingkungan pembelajaran mereka, maka semakin tinggi tingkat well-being mereka di sekolah (Chen chen and Fury, 2017 ; Tharani, Husain, Warwick, 2017). Dari dimensi peer relation, semakin siswa merasa puas dengan hubungan pertemanan mereka di sekolah, maka semakin tinggi SWB mereka di sekolah (Wijayanti \& Sulistiobudhi, 2018; Capella et al, 2014). Siswa yang merasa puas dengan hubungan pertemanan mereka ditunjukkan dengan hubungan social yang baik, merasa dihargai, diajak berteman, dan saling memberikan dukungan.

Sementara itu, dari dimensi pengajaran, pembelajaran yang berpusat pada siswa (student centered), guru yang suportif mau membantu saat siswa menemui kesulitan dan pembelajaran yang berorintasi pada pendekatan konstruktif berkorelasi positif dengan SWB di sekolah (Chen chen and Fury, 2017 : Hughes and Kwok, 2007). Tian et al (2016) menemukan bahwa school related support : teacher support and classmate support (dukungan guru dan dukungan teman sekelas) berkorelasi secara signifikan terhadap subjective wellbeing siswa di sekolah. So \& Brush (2008) menemukan bahwa terdapat hubungan yang positif antara kepuasan siswa terhadap proses pembelajaran dengan lingkungan belajar yang kolaboratif, sementara itu lingkungan belajar yang dikarakterkan mempunyai aktivitas yang bermakna akan mendorong kemandirian siswa dan keterlibatan siswa.

Dalam penelitian ini, yang menjadi sasaran dari program adalah guru dan siswa. Pentingnya dimensi peer relation (hubungan antar siswa) dan academic teaching terhadap SWB di sekolah menjadi alasan mengapa program ini diberikan ke guru dan ke siswa. Wijayanti \& Sulistiobudhi (2018) menemukan bahwa hubungan sosial antar siswa menjadi prediktor tertinggi dari kesejahteraan siswa di sekolah. Cappella et.al (2014) menyatakan pula bahwa hubungan pertemanan dapat menjadi resources yang dimiliki siswa dalam kelas sehingga meningkatkan kualitas pembelajaran dan juga memprediksi munculnya engagement atau keterikatan positif pada proses akademik yang dijalani. Selain peer relation, pendekatan dalam mengajar juga berkontibusi dalam menciptakan well-being siswa. Tharani, Husan dan Warwick (2017) menemukan bahwa pendekatan mengajar, harapan akan akademis dan ketersediaan sumber-sumber pembelajaran menjadi prediktor tertinggi dari well-being siswa di sekolah. Chen chen and Fury (2017) menemukan bahwa lingkungan pembelajaran yang berorientasi pada pendekatan konstruktivis berkorelasi positif dengan subjective well-being siswa di sekolah. Semakin positif pendekatan mengajar yang berorientasi pada pendekatan konstruktivis maka semakin siswa tinggi subjective wellbeing pada siswa.

Program peningkatan SWB ini terdiri dari 2 sasaran subjek, yaitu siswa dan guru. Untuk guru, akan diberikan pelatihan mengenai pendekatan konstruktivis dalam mengajar. Beberapa penelitian mendokumentasikan adanya hubungan yang positif antara lingkungan pembelajaran (dengan beberapa pendekatan yang konstruktivis) dengan prestasi (Harris, Santangelo, \& Graham, 2008; Mason, 2004; Weinberger \& McComs, 2001). Pendekatan konstruktivis merupakan salah satu pendekatan dalam belajar dimana para pembelajar membangun pengetahuan untuk diri mereka sendiri, dan setiap pembelajar membangun makna seperti yang mereka pelajari (Hein, 1991). Pendekatan pembelajaran konstruktivis yang menekankan keterlibatan siswa untuk membangun pengetahuannya sendiri dan meminta siswa untuk memaknai dari aktivitas yang ia pelajari sangat erat kaitannya dengan psikologi positif. Cohen (2006) menemukan adanya hubungan antara lingkungan pembelajaran dengan metode konstruktivist dengan well-being. Psikologi positif berasumsi bahwa keterlibatan dan pemaknaan yang menjadi khas dalam pendekatan konstruktivis adalah dua indikator yang penting dari well-being. Berdasarkan pendekatan konstruktivis, pembelajaran dianggap sebagai proses dari proses konstruksi aktif untuk membangun pengalaman. Sebagai hasilnya, pendekatan belajar yang konstruktivis harus memberikan perhatian yang besar terhadap proses dari pembangunan pengetahuan (misalnya membangun high-quality thinking) dan membantu siswa untuk memahami struktur dan proses dari konstruksi tersebut (Moreno \& Mayer, 1999). Lingkungan pembelajaran yang efektif harusnya membantu siswa bertanggung jawab terhadap pembelajaran mereka sendiri (Vermunt, 2003) dan mendukung interaksi dan kerjasama dengan guru dan para siswa untuk menumbuhkan inisiatif dan proaktif dalam proses pembelajaran (Van Merrienboer \& Paas, 2003).

Untuk siswa, akan diberikan pelatihan dengan berbasis experiential learning untuk membangun empati, kerjasama dan jiwa sosial antar teman. Wijayanti dan Suliostiobudhi (2018) melaporkan bahwa Peer Relation (hubungan dengan teman sebaya) secara signifikan dapat mempengaruhi perasaan siswa di sekolah. Hubungan yang positif berarti ketika relasi pertemanan sebaya para murid sekolah dasar berlangsung dengan terbuka, mereka memiliki banyak teman, dapat melakukan aktivitas bermain bersama maka akan meminimalisir munculnya perasaan negatif terhadap situasi sekolah. Sebaliknya, ketika mereka terabaikan secara sosial di sekolah, tidak memiliki peers, tidak banyak bermain dan bersosialisasi secara terbuka dengan rekan-rekannya maka dapat memprediksi munculnya perasaan sedih. Sekolah dimana para siswanya menunjukkan tingkat well-being yang tinggi, maka iklim sekolah akan semakin positif. Sebaliknya, sekolah yang didominasi oleh emosi 
negative maka iklim sekolah akan negatif. Begitu juga dengan ruang kelas. Sebuah kelas dimana para siswanya banyak yang mempunyai well-being yang tinggi, maka iklim kelas positif akan semakin muncul, sementara ruang kelas dimana siswanya mempunyai well-being yang rendah maka iklim kelas akan menjadi negatif (King \& Datu, 2017). Pentingnya akan peran teman sebaya terhadap peningkatan Subjective well-being pada remaja juga dibuktikkan oleh beberapa penelitian yang melaporkan bahwa dukungan teman sekelas mempunyai pengaruh yang signifikan terhadap subjective well-being siswa. Siswa yang mempersepsi temannya memberikan dukungan yang tinggi akan mempunyai kepuasan terhadap sekolah yang lebih tinggi pula (Danielsen et al, 2009; Jiang et al, 2013; Tian et al, 2013).

Salah satu resep utama dalam menciptakan komponen kelas yang positif adalah adanya empati di dalam ruang kelas. Konrath, O’Brien, \& Hsing (2011) dalam bukunya Twelve Stpes to a Compassionate Life, menyatakan bahwa empati dan perasaan belas kasihan bukan hanya komposisi penting untuk terciptanya wellbeing dari sebuah kebudayaan, meliankan juga jalan yang fundamental untuk mencapai kebahagiaan individu. Konflik dan isolasi diantara para individu dan kelompok mempunyai dampak yang buru baik pada tingkat masyarakat social, nasional dan global. Namun, dengan adanya empati ini dapat melawan isolasi sosial dan konflik dengan membantu orang-orang untuk saling berelasi membangun kerjasama dan persatuan. Misalnya, seorang siswa yang memahami temannya sedang mengalami kesulitan dalam memahami materi pelajaran kalkulus, maka akan membantu temannya untuk bisa paham dalam materi tersebut. Konrath, O'Brien dan Hsing (2011) juga menekankan bahwa adanya empati pada seseorang atau sekelompok budaya akan mendorong kerjasama antar individu yang ada di dalamnya. Hal ini dikarekan empati adalah aksi imaginasi untuk memposisikan diri diri kita pada posisi orang lain; memahami perspektif dan perasaan mereka; dan menggunakan pemahaman tersebut untuk memandu langkah-langkah kita (Krznaric, 2015). Bahkan beberapa penelitian menunjukkan bahwa empati adalah ketrampilan kunci dari inteligensi emosi dan membangun hubungan dengan lingkungan social, dan beberapa sekolah di Eropa dan Amerika sudah mengajarkan empati dalam metode pengajaran mereka (Goleman, 1996).

Menurut Goleman (1995), layanan-layanan pendidikan merupakan setting yang ideal untuk mengembangkan empati. Seperti halnya pedagogid, program-program peningkatan empati dalam setting pendidikan akan memperkuat timbal balik dan keseimbangan antara pembelajaran siswa dan memetakan kebutuhan komunitas yang sesungguhnya. Everhart, Elliot dan Pelco (2016) mengemukakan bahwa ada beberapa cara untuk mengembangkan empati di ruang kelas, yaitu strategi yang terkenal adalah dengan memberikan siswa pengalaman untuk membangun empati dan meminta siswa untuk merefleksikan mengenai pentingnya empati melalui experiential learning dengan pertanyaan-pertanyaan "empathy, apa itu? Jadi bagaimana? Lalu sekarang apa yang harus dilakukan? Pada fase-fase prosesing, generalisasi dan mengaplikasikan di dalam expperiantial learning cycle (Driscoll, 2007).

Pentingnya akan peran guru dan teman sebaya dalam peningkatan subjective well-being siswa ini menjadikan peneliti tertarik untuk mengembangkan sebuah program peningkatan subjective well-being siswa di sekolah melalui pelatihan metode pengajaran konstruktivis pada guru dan pelatihan dukungan sosial pada siswa yang diberi nama "Peer Support and Teaching Method Program". Berdasarkan studi yang dilakukan pada sebuah SMK X Jatinangor, kelas XI Akuntasi mempunyai skor total SWB in school yang terendah dari kelas-kelas lainnya. Oleh karena itu, peneliti menggunakan kelas XI Akuntasi sebagai sasaran penelitian untuk meningkatkan subjective well-being in school tersebut. Maka dari itu pertanyaan penelitiannya adalah "apakah Peer Support and Teaching Method Program berhasil meningkatkan subjective well-being pada siswa kelas XI Akutansi di SMK X?

\section{METODE}

Metode yang digunakan dalam penelitian ini adalah metode eksperimen dengan desain penelitian one group pretest posttest design. Dalam design ini, sample diberikan pretest (tes awal) sebelum perlakuan dan setelah perlakuan sampel diberikan posttest (tes akhir). Desain ini digunakan sesuai untuk mengetahui pengaruh/ efek dari perlakuan yang diberikan kepada sampel (Christensen, 2006). Berikut merupakan tabel desain penelitian one group pretest posttest design.

Tabel 1

Desain penelitian one group prestest-posttest design

\begin{tabular}{|c|c|c|}
\hline Prestest & Treatment & Posttest \\
\hline $\mathrm{O}_{1}$ & $\mathrm{X}$ & $\mathrm{O}_{2}$ \\
\hline \multicolumn{2}{|c|}{ (Christensen, 2006) } \\
\hline
\end{tabular}

Subjek dalam penelitian ini berjumlah 32 siswa kelas XI Akuntansi sebuah SMK di Jatianangor. Subjek penelitian ini diambil dengan menyebarkan kuesioner Subjective Well-Being in school kemudian didapatkan hasil bahwa kelas XI Akutansi mempunyai skor SWB yang terendah dari keseluruhan kelas yang ada di SMK tersebut. Pengukuran pretest dan posttest menggunakan kuesioner SWB yang diadaptasi dari kuesioner Brief Adolescent Subjective Well-Being in School (Tian et al, 2014). Alat ukur ini terdiri dari 8 item, dimana setiap item mewakili 1 dimensi. Dimensi yang terdapat dalam alat ukur ini adalah dimensi : Achievement (prestasi 
akademik), School Management (Managemen Sekolah), Teacher-student relationship (Hubungan antara siswa dengan guru), Peer relationship (Hubungan dengan teman sebaya), teaching (Pengajaran), academic learning (Pembelajaran akademis), positive affect at school (perasaan positif di sekolah), dan negative affect in school (perasaan negative di sekolah). Responden diminta untuk mengisi kuesioner dalam skala 1-6. Untuk item 1-6, pilihan jawaban 1 mengindikasikan bahwa subjek sangat tidak setuju, sedangkan pilihan jawaban 6 mengindikasikan subjek sangat setuju terhadap pernyataan tersebut. Untuk item 7-8, pilihan jawaban 1 mengindikasikan bahwa subjek tidak pernah mengalami perasaan tersebut di sekolah sedangkan pilihan jawaban 6 mengindikasikan subjek selalu mengalami perasaan tersebut di sekolah. Skor total dari kuesioner ini didapatkan dari komibnasi antara komponen kognitif dan komponen afektif. Untuk komponen kognitif didapatkan dari hasil rata-rata 6 item (item nomor 1-6), sedangkan komponen afektif didapatkan dengan mengurangi skor perasaan negatif (item 8) dengan skor perasaan positif (item 7). Dan akhirnya penjumlahan dari skor komponen afektif ditambah dengan skor komponen kognitif menjadi skor total subjective well-being siswa di sekolah. Intervensi dikembangkan dengan melalui pelatihan metode mengajar pada guru dan pelatihan sosial kepada siswa. Fokus dari program ini adalah guru dapat menerapkan metode pembelajaran yang sesuai dengan kebutuhan siswa, dan teman sekelas dapat memberikan kontribusi sosial yang dapat meningkatkan siswa. Guru akan diberikan pelatihan mengenai pendekatan metode mengajar konstruktivis yang telah dibuktikkan pada beberapa penelitian dapat meningkatkan subjective well-being siswa di sekolah (Chen chen and Fury, 2017; Harris, Santangelo, \& Graham, 2008), hal ini dikarenakan pada pendekatan konstruktivis, siswa diajak untuk lebih terlibat dalam pembelajaran dan mencari makna akan apa yang ia pelajari (Cohen, 2006).

Prinsip-prinsip pembelajaran metode konstruktivis yang diberikan dalam pelatihan ini mengutip prinsip pembelajaran konstrktivis dari Hein1(991), meliputi :

1. Pembelajaran adalah proses aktif dimana menggunakan input sensori dan membangun makna-makna pelajaran di dalamnya.

2. Pembelajaran terdiri dari membangun makna dan membangun system dari makna-makna tersebut, siswa dapat diminta untuk membuat mind mapping.

3. Aksi penting dari pembangunan makna tersebut adalah proses mental yang ada di pikiran kita. Guru perlu untuk memberikan sejumlah aktivitas yang membangun keterlibatan siswa dan membuat siswa memaknai setiap aktivitas yang dilakukannya. Aktivitas-aktivitas yang dilakukan dapat meliputi praktikum, aktivitas social, dan lain sebaginya.
4. Pembelajaran melibatkan bahasa. Guru hendaknya menggunakan Bahasa yang baik sehingga pembelajaran bisa berhasil dengan maksimal.

5. Belajar adalah aktivitas social. Metode pembelajaran konstruktivis berhubungan dengan koneksi dengan lingkungan sekitar kita, hubungan dengan guru, teman sebaya, keluarga, maka dari itu dalam pembelajaran ini, interaksi social menjadi sangat penting dan dibutuhkan.

6. Belajar adalah kontekstual. Pembelajaran metode konstruktivis ini diaplikasikan melalui kegiatan sehari-hari sehingga siswa paham akan makna dari teori yang mereka pelajari.

7. Pengetahuan yang ada akan membangun pengetahuan selanjutnya. Dalam metode ini pentingnya siswa untuk diajak memahami semakin banyak hal, karena semakin banyak yang kita tahu, anak semakin banyak yang kita pahami. Sebelum guru mengajarkan materi yang baru, akan lebih baik jika guru mereview kembali materi-materi yang telah diajarkan sebelumnya agar siswa membuat koneksi antar pengetahuan dan makna yang telah dibangun.

8. Metode ini membutuhkan waktu yang cukup banyak. Guru perlu memahami bahwa belajar bukanlah hal yang instan. Pembelajaran yang maksimal haruslah meninjau kembali ide-ide yang ada, merenungkan kembali, bermain dengan ide tersebut dan menggunakannya. Dan pembelajaran tersebut tidak bisa terjadi dalam waktu 5-10 menit.

9. Motivasi adalah komponen kunci dari pembelajaran. Oleh karena itu, memberikan metode pembelajaran yang dapat meningkatkan motivasi siswa akan lebih efektif untuk mencapai tujuan pembelajaran.

Prinsip-prinsip pembelajaran tersebut diberikan pada guru melalui psikoedukasi, sehingga guru dapat menerapkannya di ruang kelas yang mereka ajarkan. Sedangkan untuk siswa, akan diberikan pelatihan melalui metode experiential learning yang akan menumbuhkan rasa empati terhadap teman yang lain, kerjasama dan saling mendukung sehingga meningkatkan well-being siswa di dalam kelas tersebut (Danielsen et al, 2009; Jiang et al, 2013; Tian et al, 2013). Permainan yang diberikan adalah permainan si bunyi dan human rope. Permainan ini akan bertujuan untuk membangun empati, kerjasama dan dukungan social antar teman sebaya. Metode palatihan menggunakan experiential learning. Teori Experintial Learning melibatkan para siswa untuk belajar melalui empat fase yang saling terkoneksi, yaitu dengan melakukan, merasakan, mengamati, merefleksian, berpikir, dan merencanakan. Konsep teori ini menggunakan dasar bahwa siswa belajar melalui pengalaman mereka. Dalam pelatihan ini siswa akan diberikan permainan yang di dalamnya menuntut siswa 
untuk saling bekerjasama, mempunyai empati dan saling memberikan dukungan. Dengan diberikan permainanpermainan yang menunut ketiga hal tersebut, maka siswa akan belajar melalui pengalaman mereka. Dan di akhir sesi mereka akan diminta untuk merefleksikan perasaan dan pikiran mereka ketika bermain games tersebut, dan di akhir akan diminta untuk mecoba mengaplikasikan hasil dari refleksi yang telah mereka lakukan. Adapun proses dari experiential learning adalah sebagai berikut :

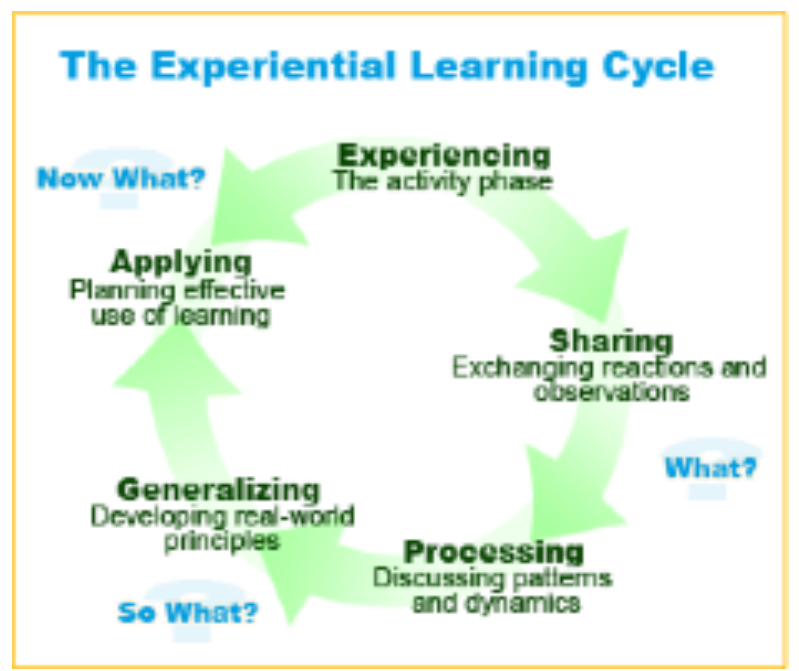

Gambar 1. Refleksi dalam kelas-kelas pembelajaran berbasis experiential learning (University of Minnesota, 2011).

Analisis statistika menggunakan Wilcoxon Signed Rank Test karena data bersifat non-parametrik. Analisis ini digunakan untuk mengetahui perbedaan antara skor pretest dan skor posttest.

\section{HASIL DAN PEMBAHASAN}

Analisis statistika menunjukkan bahwa pelatihan yang diberikan secara signifikan dapat meningkatkan subjective well-being pada siswa. Berikut hasil analisis Wilcoxon dalam table 1.

Tabel 1. Hasil Deskriptif

\begin{tabular}{|c|c|c|c|c|c|}
\hline \multicolumn{6}{|c|}{ Descriptive Statistics } \\
\hline & $\mathbf{N}$ & Mean & Deviation & Minimum & Maximum \\
\hline Pretest & 32 & 5.276 & 1.59165 & 2.67 & 7.67 \\
\hline Posttest & 32 & 9.3403 & 1.42291 & 5.37 & 11 \\
\hline
\end{tabular}

Tabel 2. Hasil Analisis

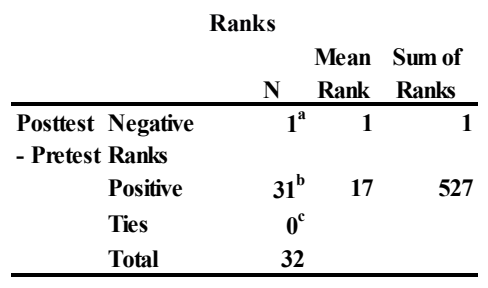

Test Statis tics ${ }^{\text {a }}$

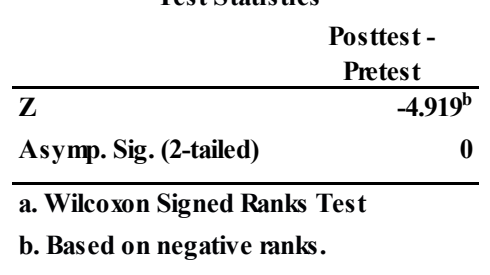

Berdasarkan analisis Wilcoxon yang dilakukan, terdapat perbedaan yang signifikan antara skor pretest dengan skor posttest yang dibuktikkan dengan nilai $\mathrm{Z}=$ $4.919, p=0.000(p<0.00)$. Untuk mengetahui perbedaan skor antara laki-laki dan perempuan, analisis statistika menggunakan independent sample T-Test, dan hasilnya dapat dilihat pada table 3 .

Tabel 3. Hasil Uji Beda

\section{Group S tatistics}

\begin{tabular}{|c|c|c|c|c|c|}
\hline & $\begin{array}{l}\text { Jeniskelam } \\
\text { in }\end{array}$ & $\mathbf{N}$ & Mean & $\begin{array}{c}\text { Std. } \\
\text { Deviati } \\
\text { on }\end{array}$ & $\begin{array}{c}\text { Std. } \\
\text { Emor } \\
\text { Mean }\end{array}$ \\
\hline \multirow[t]{2}{*}{ Pretest } & laki-laki & 16 & 5.3438 & 1.758 & 0.4395 \\
\hline & perempuan & 16 & 5.2083 & 1.4612 & 0.3653 \\
\hline \multirow[t]{2}{*}{ Posttest } & laki-laki & 16 & 9.4019 & 1.4646 & 0.3662 \\
\hline & perempuan & 16 & 9.2788 & 1.4252 & 0.3563 \\
\hline
\end{tabular}

Tidak ada perbedaan yang signifikan antara laki-laki dan perempuan, baik ketika skor pretest, 
maupun skor posttes. Pada pretest, nilai $\mathrm{F}=1.732, \mathrm{p}=$ $0.198(\mathrm{p}>0,05)$, dan pada posttest nilai $\mathrm{F}=0.11, \mathrm{p}=$ 0.917 ( $\mathrm{p}>0,05)$. Hasil ini menunjukkan bahwa terdapat pelatihan Peer Support and Teaching Method Program", mampu meningkatan subjective well-being pada siswa.

Program ini terdiri dari dua sub kegiatan. Kegiatan pertama adalah pelatihan mengajar kepada guru mengenai pendekatan konstruktivis dalam mengajar. Berdasarkan pendekatan konstruktivis, siswa memainkan peran penting terhadap pembelajaran mereka, dan pengetahuan harusnya dibangun dengan konteks yang autentis (Loyens \& Gijbels, 2008). Sementara tu, lingkungan pembelajaran yang didasarkan dengan pendekatan konstruktivis bertujuan mendukung siswa untuk melibatkan diri mereka dalam membangun pengetahuan, dan untuk mengidentifikasi makna melalui proses dari pembangunan pengetahuan dan membuat hubungannya dengan kehidupan yang sesungguhnya. Sebagai konsekuensinya, keterlibatan dan identifikasi makna akan diinduksi oleh lingkungan pembelajaran konstruktivis yang berkaitan dengan kognitif dan pengalaman afektif mereka (Chen chen and Fury, 2017). Hal ini juga didukung dengan pernyataan Cohen (2006) yang menegaskan bahwa 2 indikator penting dalam wellbeing adalah keterlibatan dan pemaknaan. Hasil penelitian ini sejalan dengan beberapa penelitian sebelumnya yang menemukan bahwa pendekatan dalam mengajar berkontibusi dalam menciptkan wel-being siswa. Tharani, Husan dan Warwick (2017) menemukan bahwa pendekatan mengajar, harapan akan akademis dan ketersediaan sumber-sumber pembelajaran menjadi prediktor tertinggi dari well-being siswa di sekolah. Lingkungan akademis mempengaruhi sebagian besar kehidupan siswa. Misalnya, sebuah lingkungan akademis yang positif dan student-centered, akan memungkinkan siswa untuk mempunyai pengalaman belajar yang konstruktif (Aghamolaei and Fazel 2010; Christie et al, 2008 ; Lizzio et al, 2002, Ni et al, 2010). Chen chen and Fury (2017) menemukan bahwa lingkungan pembelajaran yang berorientasi pada pendekatan konstruktivis berkorelasi positif dengan subjective wellbeing siswa di sekolah. Semakin positif pendekatan mengajar yang berorientasi pada pendekatan konstruktivis maka semakin siswa tinggi subjective wellbeing pada siswa.

Dalam pelatihan ini, guru diberikan pelatihan mengenai bagaimana karakteristik siswa dan metode pengajaran konstruktivis bagi siswa. Dalam pembelajaran konstruktivis, perolehan informasi bukan berlangsung satu arah dari luar ke dalam diri mahasiswa, melainkan sebagai pemberian makna oleh setiap kejadian sebagai pemberian makna oleh mahasiswa kepada pengalamannya melalui proses asimilasi dan akomodasi yang bermuara pada pemutakhiran struktur kognitifnya. Kegiatan belajar lebih dipandang dari segi prosesnya dari segi perolehan pengetahuan dari fakta-fakta yang terlepas-lepas. Pemberian makna terhadap objek dan pengalaman oleh individu tersebut tidak dilakukan sendiri oleh siswa melainkan melalui interaksi dalam jaringan sosial yang unik, yang terbentuk baik dalam budaya di kelas maupun di luar budaya kelas. Dalam proses pembelajaran ini melibatkan: peran mahasiswa, peran dosen, sarana pembelajaran, dan evaluasi (Sumarsih, 2009).

Cruickshank dkk (2006) mengemukakan definisi lain tentang pendekatan konstruktivis dalam kegiatan pembelajaran yaitu cara belajar yang bertujuan untuk memaksimalkan pemahaman siswa. Pembelajaran berbasis konstruktivis memberi kemungkinan kepada siswa untuk aktif menggali pengetahuan yang dapat meningkatkan pemahaman terhadap konsep-konsep dan prinsip-prinsip yang dipelajari.

Menurut pandangan konstruktivistik belajar merupakan suatu proses pembentukan pengetahuan. Pembentukan ini harus dilakukan individu yang belajar. Ia harus aktif melakukan kegiatan, aktif berfikir, menyusun konsep dan memberi makna tentang hal-hal yang dipelajari. Guru memang dapat dan harus mengambil prakarsa untuk menata lingkungan yang memberi peluang optimal bagi terjadinya belajar. Namun yang akhirnya paling menentukan terwujudnya gejala belajar adalah niat belajar mahasiswa itu sendiri. Dengan istilah lain dapat dikatakan bahwa pada hakikatnya kendali belajar sepenuhnya ada pada siswa (Sumarsih, 2009).

Paradigma konstruktivistik memandang mahasiswa sebagai pribadi yang memiliki kemampuan awal sebelum mempelajari sesuatu pengetahuan yang baru. Bagi kontruktivistik, kegiatan belajar adalah kegiatan aktif mahasiswa untuk menemukan sesuatu dan membangun sendiri pengetahuannya, bukan merupakan proses mekanik untuk mengumpulkan fakta. Siswalah yang bertanggungjawab atas hasil belajarnya. Siswa yang membuat penalaran atas apa yang dipelajari dengan cara mencari makna, membandingkannya dengan apa yang telah diketahui serta menyelesaikan ketidaksamaan antara apa yang telah diketahui dengan apa yang diperlukan dalam pengalaman baru. Setiap mahasiswa mempunyai cara yang cocok untuk mengkonstruksikan pengetahuannya yang kadang-kadang sangat berbeda dengan teman-teman yang lain. Dalam hal ini sangat penting bahwa siswa dimungkinkan untuk mencoba bermacam-macam cara belajar yang cocok dan juga penting bahwa guru menciptakan bermacam-macam situasi dan metode yang membantu siswa. Satu pembelajaran saja tidak akan banyak membantu siswa (Sumarsih, 2009)

Sementara bagi guru, pendidik berperan membantu agar proses pengkonstruksian pengetahuan oleh mahasiswa berjalan lancar. Pendidik tidak mentransferkan pengetahuan yang dimilikinya, melainkan membantu mahasiswa untuk membentuk pengetahuannya sendiri. Guru dituntut untuk lebih memahami jalan fikiran atau cara pandang siswa dalam belajar. Guru tidak mengklaim bahwa satu-satunya cara yang tepat adalah yang sama dan sesuai dengan 
kemampuannya (Sumarsih, 2009)

Lebih lanjut lagi, Sumarsih (2009) mengatakan bahwa dalam prinsip pembelajaran konstruktivistik, seorang pengajar atau dosen berperan sebagai mediator dan fasilitator yang membantu agar proses belajar mahasiswa berjalan dengan baik yaitu;

1. Menyediakan pengalaman belajar yang memungkinkan siswa bertanggungjawab, memberi kuliah atau ceramah bukanlah tugas utama seorang guru

2. Menyediakan atau memberikan kegiatankegiatan yang merangsang keingintahuan siswa dan membantu mereka untuk mengekspresikan gagasannya dan mengkomunikasikan ide ilmiah mereka, menyediakan sarana secara produktif menyediakan kesempatan dan pengalaman yang paling mendukung proses belajar siswa. Guru perlu menyemangati mahasiswa dan menyediakan pengalaman konflik.

3. Memonitor, mengevaluasi dan menunjukkan apakah pemikiran siswa berjalan atau tidak. Guru mempertanyakan apakah pengetahuan mahasiswa dapat diberlakukan untuk menghadapi persoalan baru yang berkaitan. Guru membantu mengevaluasi hipotesis dan kesimpulan siswa.

Dengan kegiatan-kegiatan di atas, siswa membangun pengetahuannya sendiri, sehingga ia semakin terlibat dalam kegiatan belajar yang ia alami (engagement), semakin bisa menarik makna atau memaknakan apa yang ia pelajari (meaningful), dan senang dengan aktivitasnya karena ia tidak hanya diberi namun terlibat aktif dalam pencarian dan pembangunan pengetahuan. Seligman (2002) mencatatkan bahwa tiga langkah untuk mencapai well-being, yaitu pleasure (kesenangan), engagement (keterlibatan), dan meaning (pemaknaan), sementara Cohen (2006) menyatakan bahwa keterlibatan dan pemaknaan dapat dibangun di sekolah. Keterlibatan membuat siswa menjadi lebih terlibat dan memberikan pengalaman yang memuaskan untuk mengembangkan ketertarikan, kekuatan, dan kebaikan. Menemukan makna adalah elemen penting lainnya yang berkontribusi pada perasaan well-being dan kesejahteraan kita. Positif psikologi mengasumsikan bahwa keterlibatan dan pemaknaan adalah dua indicator penting dari well-being (Cohen, 2006).

Pada sub-kegiatan kedua adalah pelatihan experiential learning pada siswa. Dalam kegiatan ini, siswa diajak untuk memainkan permainan si bunyi dan human rope, tujuannya adalah untuk meningkatkan rasa empati, kerjasama, kepedulian dan saling mendukung antar siswa. Pelatihan ini diberikan dengan pendekatan experiential learning. Experiential learning menggunakan cara yang memberikan sebuah pengalaman langsung kepada para peserta pelatihan dengan simulasi atau permainan yang secara langsung dirasakan oleh setiap peserta pelatihan. Tujuan experiential learning adalah untuk mempengaruhi peserta dalam tiga cara: (1) struktur kognitif peserta yang diubah, (2) sikap peserta yang dimodifikasi, dan (3) pengetahuan peserta tentang keterampilan perilaku diperluas. Ketiga unsur tersebut saling berhubungan dan mengubah secara keseluruhan, bukan sebagai kesatuan yang terpisah. (Johnson \& Johnson, 2000).

Menurut Kolb (1984) pengalaman mempunyai peran penting dalam pembentukan pengetahuan. Jean Piaget dalam Rifa'i \& Anni (2012) menyatakan bahwa pembentukan pengetahuan dapat dilakukan manusia melalui pengalamannya sendiri. Proses pembelajaran yang membantu siswa dalam pembentukan pengetahuan melalui transformasi pengalaman yaitu menggunakan model Experiential Learning Kolb (Kolb, 1984). Melalui permainan yang dilakukannya, siswa belajar melalui permainan tersebut dan mereka merasakan serta memaknai apa yang sedang mereka alami.

Pada permainan tersebut, tujuan pelatihan berdasarkan experiential learning adalah untuk meningkatkan rasa empati, kerjasama, kepedulian dan saling mendukung antar siswa. Dengan mempunyai teman yang suportif, menerima apa adanya dan saling bekerjasama untuk saling membantu akan meningkatkan kepuasan siswa di sekolah dan memberikan pengalaman perasaan yang positif di sekolah. Hasil ini sejalan dengan hasil penelitian Danielsen et al (2009), Jiang et al (2009) dan Tian et al (2013) yang menemukan bahwa siswa yang mempersepsi temannya memberikan dukungan yang tinggi cenderung akan mempunyai kepuasan terhadap sekolah yang lebih tinggi pula. Ketika siswa merasa kesulitan dalam pelajaran namun dapat menerima bantuan dari temannya, hal itu membuatnya merasa lebih baik di sekolah. Ia merasa tidak sendirian dan lebih mudah memahami materi pelajaran. Selain pentingnya akan kerjasama dan dukungan dari teman sebaya, peer acceptance juga menjadi hal penting bagi subjective well-being pada siswa.

Teman sebaya atau peers adalah anak-anak atau remaja dengan tingkat usia atau tingkat kedewasaan yang sama. Remaja menghabiskan semakin banyak waktu dalam interaksi teman sebaya pada remaja pertengahan, masa anak-anak, serta masa remaja. Bagi remaja hubungan teman sebaya merupakan bagian yang paling besar dalam kehidupannya (Santrock, 2003). Proses hubugan social kelompok teman sebaya merupakan urutan terpenting dalam proses sosialisasi remaja karena dalam kelompok (peer group) remaja merasakan adanya kecemasan satu dengan yang lain seperti di bidang usia, kebuthan, dan tujuan yang dapat memperkuat kelompok itu (Santosa, 2004).

Menurut Mappiare (1982) kelompok teman sebaya merupakan lingkungan social pertama dimana remaja belajar untuk hidup bersama orang lain yang bukan anggota keluarganya, lingkungan teman sebaya merupakan suatu kelompk baru, yang memiliki ciri, norma, kebiasaan yang jauh berbeda dengan apa yang ada dalam lingkungan keluarga remaja. Diterimanya remaja oleh teman sebayanya akan membuat salah satu 
kebutuhan remaja tersebut terpenuhi. Hal ini disebabkan karena penerimaan teman sebaya merupakan salah satu kelompok kebutuhan remaja, disamping kebutuhan yang berhubunan dengan para orangtua. Akibat langsung adanya penerimaan teman sebaya bagi seorang remaja adalah rasa berharga dan berarti serta dibutuhkan bagi atau oleh kelomoknya. Hal ini akan menimbulkan rasa senang, gembira, puas, bahkan rasa bahagia, yang pada gilirannya memberi rasa percya diri yang besar. Keadaan menguntungkan ini membawa pengaruh positif bagi perkembangan penyesuaian pribadi dan social yang dibawanya sampai masa dewasa (Herawaty, 2015).

Penelitian ini dilakukan pada siswa kelas XI, dimana subjek penelitian masih masuk kategori remaja, dan peer acceptance sangat mempengaruhi subjective well-being mereka. Penelitian Wetzkel et.al. (2005), Thomson et.al., (2015) dan Oberle et.al. (2013) melaporkan bahwa peer acceptance adalah tahapan perkembangan yang penting pada masa remaja, karena hal ini berkaitan dengan wellbeing pada remaja, resiliensi, dan kesuksesan di sekolah maupun di luar sekolah. Diterima oleh teman sebaya di ruang kelas ataupun sekolah merupakan hal yang penting, hal ini karena remaja menghabiskan waktu yang banyak di sekolah sehingga mereka dikelilingi dan terlibat dengan teman sebaya mereka. Hasil penelitian ini juga sejalan dengan hasil penelitian dairi Khavari (2006) yang menyebutkan bahwa ketika hubungan dengan teman dirasa memuaskan, maka pergaulan social akan membawa pengaruh penting bagi kebahagiaan seseorang, sebaliknya kurangnya penerimaan dari lingkungan social teman sebaya akan menyebabkan remaja menjadi terisolasi dari lingkungannya. Hurlock (1992) menyebutkan bahwa apabila remaja realistic terhadap derajad penerimaan yang dapat mereka capai, merasa puas pada orang-orang yang menerima mereka dan menunjukkan kasih saying pada orang0orang tersebut, maka kemungkinan untuk merasa bahagia akan meningkat.

Hasil penelitian ini bisa digunakan oleh beberapa pemangku kebijakan di sekolah agar mereka dapat meningkatkan subjective well-being siswa. Dengan adanya subjective well-being yang meningkat, maka prestasi akademis pun bisa meningkat.

\section{SIMPULAN}

Hasil penelitian ini membutikkan bahwa pelatihan "Peer Support and Teaching Method Program" berhasil meningkatkan subjective well-being pada siswa. Dengan adanya dukungan, bantuan dan penerimaan dari teman sekelas, siswa akan lebih mudah memahami materi pelajaran dan mempunyai perasaan positif di sekolah. Selain dari teman sebaya, pendekatan akan metode mengajar menjadi penting dalam meningkatkan subjective well-being siswa. Pendekatan mengajar yang konstruktivis dimana siswa diajak untuk lebih terlibat dalam membangun pengetahuan mereka sendiri cenderung akan membuat siswa lebih puas di sekolah. Keterlibatan dan pencarian akan makna dari apa yang mereka pelajari membuat mereka mempunyai tingkat kepuasaan yang lebih tinggi dan perasaan yang lebih baik di sekolah.

Bagaimanapun, penelitian ini tidak luput dari kekurangan. Untuk penelitian lebih jauh lagi, peneliti bisa mengidentifikasi sejauh mana pengaruhnya terhadap nilai akademis mereka. Hal ini agar bisa menjadi data tambahan seberapa jauh program ini dapat meningkatkan nilai akademis para siswa.

\section{DAFTAR PUSTAKA}

Abele A (1995) Stimmung und Leistung: allgemein- und sozial psychologische Perspektive. Hogrefe, Göttingen, Germany

Bernard, M., \& Walton, K. (2011). The effect of You Can Do It! Education in six schools on student perceptions of well-being, teaching, learning and relationship. Journal od Student Wellbeing, 5, 22-37. https://doi.org.10.21913/JSW.v5il.679

Cappella, E., Kim, H. Y., Neal, J. W., \& Jackson, D. R. (2013). Classroom peer relationships and behavioral engagement in elementary school: The role of social network equity. American journal of community psychology, 52(3-4), 367379.

Chen, Chen., Fan, Jieqiong., Jury, Mickael. Are perceived learning environment. Learning and Individual Differences : 54 (2017) pg 226 - 233

Cohen, J. (2006). Social, emotional, ethical, and academic education: Creating a climate for learning, participation in democracy, and wellbeing. Harvard Educational Review, 76(2), 201-237.

Cruickshank. D.R, Jenkin D. B., dan Metcalf. K. (2006). The Act of Teaching. New York: Me Graw Hill.

Danielsen, A. G., Samdal, O., Hetland, J., \& Wold, B. (2009). School-related social support and students'perceived life satisfaction. The Journal of Educational Research, 102(4), 303-320. doi:10.3200/JOER. 102.4.303-320.

Diener, E., Lucas, R. E., \& Oishi, S. (2002). The Science of Happiness and Life Satisfaction. In C. R. Snyder \& S. J. Lopez (eds.) Handbook of Positive Psychology (pp.63-73). New York: Oxford University Press. 
Diener, E., Wirtz, D., Tov, W., Kim-Prieto, C., Choi, D., Oishi, S., \& Biswas-Diener, R. (2009). New measures of well-being: Flourishing and positive and negative feelings. Social Indicators Research, 39, 247-266. https://doi.org/10.1007/978-90-481-2354-4_12

Everhart, R., Elliot, Katie, Pelco, Lynn E. (2016). Empathy Activators: Teaching Tools for Enhancing Empathy Development in Service Learning Classes. Virginia Commonwealth University : VCU Scholars Compass

Greene TR, Noice H (1988) Influence of positive affect upon creative thinking and problem solving in children. Psychol Rep 63:895898.doi:10.2466/pr0.1988.63.3.895

Goleman, Daniel. (1996). Emotional Intelligence; Why It Can Matter More than IQ. London : Bloomsbury

Goleman, D. (1995). Emotional intelligence. New York: Bantam.

Harris, K. R., Santangelo, T., \& Graham, S. (2008). Selfregulated strategy development in writing: Going beyond NLEs to a more balanced approach. Instructional Science, 36(5-6), 395408.

Hein, George E. (1991). Constructivist Learning Theory. CECA (International Committee of Museum Educators) Conference.

Herawaty, Yulia. (2015). Hubungan antara penerimaan teman sebaya dengan kebahagiaan pada remaja. An-Nafs, Vol.09, No. 03.

Hughes, J. N., \& Kwok, O. (2007). The influence of student-teacher and parent-teacher relationships on lower achieving readers' engagement and achievement in the primary grades. Journal of Educational Psychology, 99, $39-51$.

Huppert, F., \& Johnson, D. (2010). A controlled trial of mindfulness training in schools: The importance of practice for an impacton well-being. The Journal of Positive Psychology, 5, 264-274. https://doi.org/10.1080/17439761003794148

Hurlock, E. B. (1992). Psikologi Perkembangan Suatu Pendekatan Sepanjang Rentang Kehidupan: edisi kelima (Terjemahan). Jakarta: Erlangga
Isen AM. (2008). Some ways in which positive affect influences decision making and problem solving. In: Lewis M, Haviland-Jones JM, Feldmann Barrett L (eds) Handbook of emotions. Guilford, New York, pp 548-573

Johnson W, Kyvik KO, Mortensen EL, Skytthe A, Batty GD, Deary IJ (2010) Education reduces the effects of genetic susceptibilities to poor physical health. Int J Epidemiol 39:406-414. doi:10.1093/ije/dyp314

Jiang, X., Huebner, E. S., \& Siddall, J. (2013). A shortterm longitudinal study of differential sources of school-related social support and adolescents' school satisfaction. Social Indicators Research, 114(3), 1073-1086. doi:10.1007/s11205-012-0190-x.

Khavari, K.A. (2006). The Art of Happiness: Mencipta Kebahagiaan dalam Setiap Keadaan. Jakarta: Ikrar Mandiri Abadi

King, Ronnel B., Datu, Jesus Alfonso. (2017). Happy classes make happy students: Classmates' wellbeing predicts individual student well-being. Journal of School Psychology, 65, 116-128.

Kolb D.A. 1984. Experiential Learning: Experience As The Source Of Learning And Development. New Jersey: Prentice Hall

Mason, L. H. (2004). Explicit self-regulated strategy development versus reciprocal questioning: Effects on expository reading comprehension among struggling readers. Journal of Educational Psychology, 96(2), 283-296.

Mappiare, A. (1982). Psikologi Remaja. Surabaya: Usaha Nasional

Moreno, R., \& Mayer, R. E. (1999).Multimediasupported metaphors formeaningmaking in mathematics. Cognition and Instruction, 17(3), 215-248.

Morris, I. (2009). Learning to ride elephants: Teaching happiness and well-being in schools. London: Continuum.

National Scientific Council on the Developing Child (2006). Children's emotional development is built into the architecture of their brains. Report $2 . \quad$ Retrieved from www.developingchild.net. 
Peterson, C., \& Seligman, M. E. P. (2004). Character strengths and virtues: A classification and handbook. New York: Oxford University Press/Washington, DC: American Psychological Association.

Rifa'i A. \& C. T. Anni. 2012. Psikologi Pendidikan. Semarang: UPT Unnes Press

Roeser RW, Eccles JS, Freedman-Doan C (1999) Academic functioning and mental health in adolescence: patterns, progressions, and routes from childhood. J Adolesc Res 14:135-174. doi:10.1177/0743558499142002

Santosa, S. (2004). Dinamika Kelompok: Edisi Revisi. Jakarta: Bumi Aksara.

Santrock, J.W. (2003). Adolescence Perkembangan Remaja: Edisi Enam (Terjemahan). Jakarta: Erlangga

Seligman, M. E. P. (2011). Flourish: A Visionary New Understanding of Happiness and Well-Being. New York: Free Press.

Seligman, M. E. P., Ernst, R. M., Gillham, J., Reivich, K., \& Linkins, M. (2009). Positive education: positive psychology and classroom interventions. Oxford Review of Education, 35(3),293-311.

https://doi.org/10.1080/03054980902934563

Seligman, M. E. P. (2002). Authentic happiness: Using the new positive psychology to realize your potential for lasting fulfillment. New York, NY, US: Free Press

Shoshani, A., Sarit, Steinmetz. (2014). Positive Psychology at School : A school-Based Intervention to promote adolescents' Mental Health and Well-Being. Journal Happiness Studies 15:1289-1311

So, H. -J., \& Brush, T. A. (2008). Student perceptions of collaborative learning, social presence and satisfaction in a blended learning environment: Relationships and critical factors. Computers \& Education, 51(1), 318-336.

Spence, S., \& Shortt, A. L. (2007) Research review: can we justify the widespread dissemination of universal school-based interventions for the prevention of depression among children and adolescents? Journal of Child Psychology and Psychiatry,48,526-542. https://doi.org/10.1111/j.1469-

7610.2007.01738.x

Sumarsih. Implementasi Teori Pembelajara Konstruktivistik Dalam Pembelajaran Mata Kuliah Dasar-Dasar Bisnis. Jurnal Pendidikan Akuntansi Indonesia. Vol VIII No. 1: 54 -62

Tennant, J. E., Demaray, M. K., Malecki, C. K., Terry, M. N., Clary, M., \& Elzinga, N. (2015). Students' ratings of teacher support and academic and social-emotional wellbeing. School Psychology Quarterly, 30(4), 494.

Tharani, Ambreen., Husain, Yusra., Warwick, Ian. (2017). Learning Environment and Emotional Well-being : A qualitative study of undergraduate nursing students. Nurse Education Today $59: 82-87$

Tian, L., Liu, B., Huang, S., \& Huebner, E. S. (2013). Perceived social support and school well-being among Chinese early and middle adolescents: The mediational role of self-esteem. Social Indicators Research, 113(3), 991-1008. doi:10.1007/s11205-012-0123-8.

Tian, Lili., Wang, Dushen., Huebner, E.S. (2014). Development and Validation of the Brief Adolescents' Subjective Well-Being in School Scale (BASWBSS). Social Indicator Research. DOI 10.1007/s11205-014-0603-0

Tian, Lili., Tian, Qinqin, Huebner, E Scott. (2016). School Related Social Support and Adolescents' School-Related Subjective Well-Being : The Mediating Role of Basic Psychological Needs Satisfaction at School. Social Indication Research. 128:105-129

University of Minnesota Center for Community-Engaged Learning. (2011). Reflection in service-learning classes. Retrieved from http://www.servicelearning.umn.edu/info/reflect ion.html

Van Merriënboer, J. J. G., \& Paas, F. (2003). Powerful learning and the many faces of instructional design: Toward a framework for the design of powerful learning environments.

In E. D. Corte, L. Verschaffel, N. Entwistle, \& J. J. G. van Merriënboer (Eds.), Powerful learning environments: Unravelling basic components and dimensions (pp. 3-20). Oxford, UK: Elsevier Science. 
Vermunt, J. D. (2003). The power of learning environments and the quality of student learning. In E. D. Corte, L. Verschaffel, N. Entwistle, \& J. J. G. van Merriënboer (Eds.), Powerful learning environments: Unravelling basic components and dimensions (pp. 109124). Oxford, UK: Elsevier Science.

Waters, L. (2011). A Review of School-based Positive Psychology Interventions. The Australian Educational and Developmental Psychologist, 28(2),75-90.

https://doi.org/10.1375/aedp.28.2.75

Weinberger, E., \&McCombs, B. L. (2001). The impact of learner-centered practices on the academic and non-academic outcomes of upper elementary and middle school students. (Paper presented at the The Annual Convention of the American Educational Research Association, Seattle).

Wijayanti, Puspita Adhi., Suliostibudhi, Rezki A. (2018). Peer Relation Sebagai Prediktor Utama School Well-Being Siswa Sekolah Dasar. Jurnal Psikologi Vol. 17 No. 1 April 2018, 89-104.

Konrath, S. H., O'Brien, E. H., \& Hsing, C. (2011). Changes in dispositional empathy in American college students over time: a meta- analysis. Personality and Social Psychology Review, 15, 180-198.

Krznaric, Roman. (2015). The Empathy Effect: How Empathy Drives Common Values, Social Justice and Environmental Action. London: Friends of the Earth

Yates, L. (2007). Zlearning to ,become somebody well ${ }^{\text {ee }}$ Challenges for Educational Policy. The Australian Educational Researcher, 34, 35-52. https://doi.org/10.1007/BF03216864 